\title{
Razem czy osobno? Znaczenie płci w szkolnej nauce języka obcego
}

\section{Together or separately? The importance of gender in learning a foreign language at school}

\author{
Marcin Legeżyński, \\ Szkoła Podstawowa "Skrzydła” Fundacji Sternik Poznań
}

\begin{abstract}
The study deals with the most important differences visible in the process of learning a foreign language between male and female students. The author of the text analyzes the reasons for these differences at the level of physiology and psychology of students and lists the most important elements that should be present in a differentiated education lesson.
\end{abstract}

Key words: Single-sex education, gender, motivation, motivating techniques, social status, learning foreign languages.

Streszczenie: Opracowanie podejmuje temat najważniejszych różnic widocznych w procesie uczenia się języka obcego pomiędzy uczniami płci męskiej i żeńskiej. Autor tekstu analizuje przyczyny tych różnic na poziomie fizjologii i psychologii uczniów oraz wymienia najważniejsze elementy, które powinny być obecne w lekcji edukacji zróżnicowanej.

Słowa kluczowe: edukacja zróżnicowana, płeć, motywacja, techniki motywujące, status społeczny, nauka języków obcych

Zastanawiając się nad sposobem uczczenia pamięci pani profesor Bożeny Chrząstowskiej, zaprzyjaźnionej wprawdzie z moimi rodzicami, lecz dla mnie pozostającej głównie autorką książek z ich biblioteki, zdecydowałem się pozostać na gruncie bliskiej Jej metodyki nauczania. Nauczania języka - ponieważ wiem, że obok problemów literaturoznawczych zawsze żywo obchodziły Ją lingwistyczne aspekty edukacji. Nauczania języka obcego - ponieważ w tym zakresie mieszczą się moje zainteresowania i kompetencje anglisty.

Zagadnienie, które tu najogólniej przedstawię, ma charakter interdyscyplinarny i mieści się w nurcie badań stosunkowo szeroko omawianych $\mathrm{w}$ anglojęzycznej literaturze przedmiotu. Zamierzam więc podsumować prezentowane $\mathrm{w}$ niej ustalenia na temat najważniejszych różnic widocznych $\mathrm{w}$ procesie uczenia się języka obcego pomiędzy uczniami 
płci męskiej i żeńskiej. Zagadnienie to wypełniło jeden z rozdziałów mojej pracy dotyczącej metodyki nauczania języków obcych pt. How to increase motivation for learning a foreign language in a single-sex school? (Oxford 2020). Zgłębiając literaturę przedmiotu, dotarłem do wielu nietłumaczonych na język polski opracowań, z których zaledwie część wskażę w stosunkowo obszernej bibliografii umieszczonej na końcu artykułu. Materiał ten, jak sądzę, może mieć praktyczne znaczenie w projektowaniu metod nauczania, a także szerzej, w dyskusji o koedukacyjnym lub rozdzielnym trybie dydaktyki.

Większość dostępnych obecnie opublikowanych wyników badań naukowych nie ujmuje różnic międzypłciowych jako jednego z istotnych czynników wpływających na proces uczenia się, wpisując się tym samym - być może - w poprawny politycznie, choć dość oderwany od rzeczywistości edukacyjnej trend traktowania obu płci w identyczny sposób. Różnice te jednak istnieją. Zaskakiwać może także fakt, że w przypadku nauki języków obcych ich skala zwiększa się wraz z upływem czasu.

Dobrym tego przykładem może być badanie przeprowadzone przez Van der Slika, Van Houta i Schepensa w 2015 roku na grupie 2700 imigrantów uczących się języka niderlandzkiego jako języka obcego w Holandii. Badana populacja pochodziła z 88 państw i posługiwała się 49 różnymi językami ojczystymi, zarówno indoeuropejskimi, jak też innymi. Dane użyte do badań pochodziły z oficjalnego testu państwowego (State Examination of Dutch as a Second Language) przeprowadzonego w latach 1995-2004 i obejmowały szeroki zakres kompetencji: pisanie, czytanie, rozumienie ze słuchu oraz mowę. Analiza wyników badań pozwoliła badaczom na udowodnienie istnienia znaczącej przewagi kobiet nad mężczyznami w nauce języka obcego, która zwiększała się w miarę upływu czasu nauki.

W znanej, dawno wydanej książce Brain Sex (Płeć mózgu) autorzy, David Jessel i AnneMoir, dowodzili istnienia „prawdziwych różnic między mężczyzną a kobietą". Wczesne badania nad rolą płci w procesie uczenia się podjęte przez Clare Burstall (1975), jak również bardziej współczesne, przeprowadzone przez Trevora McDonalda i Johna Boyda z Nuffield Foundation (2000) oraz Beatrice Davies (2004), potwierdzają przewagę dziewczynek nad chłopcami w nauce języka obcego i sugerują konieczność dostosowania strategii dydaktycznych do tych różnic. Zadaniem kluczowym wydaje się więc odpowiednie przygotowanie pedagogów do efektywnego wykorzystania - zróżnicowanych ze względu na płeć - technik motywujących uczniów do nauki. W odpowiedzi na pytanie, jak to zrobić, pomoże rzut oka na ogólną koncepcję edukacji zróżnicowanej ze względu na płeć.

Dyskusja nad wyższością edukacji koedukacyjnej toczy się w świecie pedagogiki od dawna. Oba modele mają prawdopodobnie tak wielu zwolenników, jak i przeciwników. Pod względem kryterium płci uczniów edukacja funkcjonuje obecnie w co najmniej trzech postaciach: szkół koedukacyjnych, klas jednopłciowych w szkołach koedukacyjnych oraz szkół tzw. edukacji 
zróżnicowanej, czyli jednopłciowych. Efektywność klas i szkół jednopłciowych jest potwierdzana przez większość badaczy, choć dostępne opracowania nie są zgodne co do wielkości tej przewagi nad modelem koedukacyjnym. Spektrum opinii oscyluje między jedną z niewielu przeprowadzonych dotąd metaanaliz zagadnienia edukacji zróżnicowanej w pracy Margaret Signorelli, Amy Roberson Hayes i Yidi Li (2013), którzy dostrzegają jedynie marginalnie lepsze wyniki nauczania języka w szkole jednopłciowej, a wyraźnie lepszymi wynikami zaobserwowanymi w edukacji zróżnicowanej przez Sheree Gibb i innych (2008), którzy równocześnie stwierdzają, że dziewczynki osiągają zdecydowanie większą korzyść z edukacji jednopłciowej niż chłopcy.

Inni badacze zwracają także uwagę na społeczny wymiar funkcjonowania uczniów w jednopłciowym środowisku szkolnym. Teresa Mendez (2004) przestrzega przed zgubnym, jej zdaniem, wpływem takiego środowiska na rozwój społeczny uczniów, którzy mogą napotkać problemy w późniejszych relacjach z płcią przeciwną. Ryzyko to jest jednak niwelowane, zdaniem innych, przez wpływ środowiska rodzinnego czy koleżeńskiego, w którym uczniowie $\mathrm{w}$ naturalny sposób doświadczają międzypłciowych relacji społecznych. Teresa Hughes (2007) kładzie nacisk na pierwszorzędny cel szkoły, jakim jest rozwój wiedzy i umiejętności merytorycznych uczniów, a jedynie w ograniczonym wymiarze rozwój społeczny.

Niektórzy znawcy, idąc drogą kompromisu, proponują dostosowanie strategii nauczania do różnic międzypłciowych przy zachowaniu koedukacyjnej formy szkoły. David Kommer (2006) sugeruje pracę z uczniami w sekwencji naprzemiennych ćwiczeń językowych dostosowanych do specyfiki płci oraz niedostosowanych do niej. Takie postępowanie miałoby na celu „przyzwyczajenie” uczniów do funkcjonowania w dwupłciowej rzeczywistości, wykorzystując jednocześnie ich specyficzne cechy i różnice w jak największej optymalizacji procesu nauczania.

W ostatnim czasie szczególnie popularnym tematem badań nad edukacją zróżnicowaną są neurologiczne różnice w funkcjonowaniu dziewczynek i chłopców. Jednym z autorytetów w tej dziedzinie stał się Leonard Sax z University of Pennsylvania. W swych pracach podkreśla on znaczne różnice między rozwojem mózgu u obu płci, które powinny determinować nie tylko metodykę nauczania, ale wręcz sposób wychowywania dzieci przez rodziców. Sax wymienia szereg ważnych różnic płciowych mających wpływ na procesy poznawcze. Należy do nich zmysł słuchu, o 38\% sprawniejszy na pewnych etapach rozwoju u dziewcząt niż u chłopców. Należy też zdolność odczytywania i interpretowania mimiki, bardziej rozwinięta u dziewcząt, co Sax przypisuje chemicznym różnicom w budowie oka i receptorów mózgowych. Badacz dostrzega również bardziej rozwiniętą u chłopców wyobraźnię przestrzenną, przydatną $\mathrm{w}$ naukach ścisłych oraz przewagę dziewcząt w mowie i piśmie, przypisywaną większym rozmiarom corpuscallosum, czyli spoidła mózgu - ciała modzelowatego (Sax 2005). Spostrzeżenia te 
podzielają inni badacze. Diane Halpern i inni (2007) wskazują na lepszy rozwój kory mózgowej w prawej półkuli u chłopców jako na możliwą przyczynę ich przewagi w zadaniach wymagających wyobraźni przestrzennej. Inni sugerują, że lepszy rozwój płata czołowego mózgu oraz kory przedczołowej (prefrontalcortex) u dziewcząt jest powodem, dla którego osiągają one lepsze wyniki w naukach humanistycznych. Pewna grupa badaczy, wśród nich Cornelius Riordan (2015), ostrzega jednak przed pochopnym wyciąganiem wniosków z wymienionych różnic i bezpośrednim przekładaniem ich na praktyczny wymiar pracy z uczniami w szkole bez uwzględniania indywidualnych różnic między jednostkami.

Poza analizą fizjologicznych różnic w budowie mózgu obu płci trwają również badania nad znaczeniem pewnych mechanizmów hormonalnych, które w rozmaity sposób mogą wpływać na to, jak uczą się chłopcy i dziewczęta. Hormony te - wbrew temu, co dawniej sądzono - aktywne są we wszystkich strukturach mózgowych, a nie jedynie w podwzgórzu. Szczególnie mocno wydzielane są jednak w hipokampie, który odgrywa rolę w procesie zapamiętywania i uczenia się (McEwen, Milner 2017). Innym istotnym obszarem badań są tzw. etapy sensytywne w rozwoju dzieci, które - jak się wydaje - również przebiegają odmiennie u obu płci. Są to okresy, w których pewne części mózgu lub procesy mózgowe stają się wyjątkowo silne. Na przykład rozwój umiejętności matematycznych zachodzi w rozwoju chłopców wcześniej niż u dziewczynek, co może skutkować ich gorszymi wynikami nauki na wczesnych etapach edukacji. Odwrotnie rzecz ma się z rozwojem umiejętności językowych, który rozpoczyna się wcześniej u dziewcząt. Świadomość tych sekwencji powinna więc wywierać wpływ na planowanie nauczania chłopców i dziewcząt (Spielhofer, Benton, Schagen 2004).

Kwestia dyscypliny uczniów podczas zajęć szkolnych jest także zdeterminowana przez ich płeć. Stereotypowy obraz niesfornych chłopców i grzecznych dziewczynek potwierdza część badań naukowych (Francis 2004). Statystyczny chłopiec jest 20 razy bardziej skłonny do stosowania przemocy w szkole (Lever 1976). Chłopcy angażują się w ostre spory dość często, jednak szybko puszczają niesnaski w niepamięć i kontynuują przyjaźnie mimo wcześniejszych sporów. Dziewczęta z kolei, choć inicjują konflikty rzadziej, to gdy już do nich dojdzie, często eskalują spory, używając o wiele bardziej agresywnego językai znacznie trudniej przychodzi im godzić się z innymi. Na wczesnych etapach edukacyjnych większa skłonność chłopców do przemocy znajduje wyraz nawet w wyborze tematów rysunków.

Wszystkie te uwarunkowania mają wielki wpływ na funkcjonowanie uczniów podczas lekcji i na kontakt z nauczycielami. Zaobserwowano na przykład, że dziewczęta dużo łatwiej nawiązują pozytywne i przyjazne relacje $\mathrm{z}$ nauczycielami, a wskutek tego bardziej angażują się $\mathrm{w}$ naukę materiału, który niekoniecznie wydaje im się atrakcyjny. Chłopcy z kolei trudniej znoszą nieatrakcyjne tematy i częściej na takich lekcjach przeszkadzają (Duckworth, Seligman 2006). Bazując na dobrych stosunkach 
z nauczycielem, dziewczynki chętniej korzystają z jego wsparcia w przypadku napotkania zbyt trudnych zadań. W klasie taka współpraca z nauczycielem podnosi bowiem status społeczny uczennicy. Podobne zachowanie u chłopców oznaczałoby jednak obniżenie statusu społecznego, więc chłopcy znacznie rzadziej proszą nauczyciela o pomoc, wybierając rozmowy z kolegami i przeszkadzanie w zajęciach (Sax 2005). Relacje z nauczycielem znajdują odzwierciedlenie także i w sposobie kontaktu wzrokowego. Dziewczynki na ogół czują się lepiej, utrzymując kontakt wzrokowy, podczas gdy chłopcy instynktownie odbierają taki kontakt jako oznakę wrogości (Sax 2005, 141). Wydaje się więc oczywiste, że stosowanie przez nauczycieli zróżnicowanych zachowań wobec dziewczynek i chłopców powinno być pomocne w nauczaniu.

Innym istotnym aspektem nauczania jest stosowanie elementów rywalizacji w czasie lekcji. Tradycyjnie uważa się je za atrakcyjne urozmaicenie nauki. Interesująca może się jednak okazać analiza efektywności strategii dydaktycznych w zależności od płci uczniów. Zauważono na przykład, że dziewczynki wykonują zadania edukacyjne ze znacznie gorszymi wynikami od chłopców, jeśli stosowany jest element rywalizacji. Natomiast ich wyniki są znacząco lepsze, gdy wykonują te same zadania, nie rywalizując z innymi. Uri Gneezy i Aldo Rustichini (2003) dochodzą do takich wniosków zarówno w badaniach zadań lekcyjnych, jak i sportowych. Natomiast Alison Booth i Patrick Nolen (2012) stwierdzają porównywalną preferencję zadań zawierających element rywalizacji zarówno u dziewcząt, jak i u chłopców po warunkiem, że są one przeprowadzane w grupie niekoedukacyjnej. Wnioskować zatem można, że dziewczęta niechętnie rywalizują w takich sytuacjach z chłopcami, natomiast dobrze radzą sobie w grupach żeńskich. Chłopcy z kolei - jak się wydaje - nie podlegają podobnym ograniczeniom. Do zbliżonych wniosków dochodzą Muriel Niederle i Lise Vesterlund (2010) w badaniu szkolnych zadań matematycznych realizowanych przez uczniów obu płci. Część badaczy tłumaczy skłonność chłopców do rywalizacji ich większym zamiłowaniem do podejmowania ryzyka. Jak twierdzą James Byrnes, David Miller i William Schafer (1999), większość chłopców lubi podejmować ryzykowne zachowania, których dziewczęta unikają.

Jak jednak przedstawione różnice wpływają na specyfikę nauki języków przez uczniów obu płci? Większość badaczy podkreśla generalnie większą tendencję chłopców do wczesnego zniechęcenia się do nauki języka (Gardner, Lambert 1972). Dobór technik motywujących uczniów powinien zatem być uzależniony od ich płci. Przyjmuje się, że chłopcy lepiej reagują na techniki motywacji instrumentalnej. Tak więc wszelkie systemy punktów, plusów pisanych na tablicy, premiowania wysiłku na lekcji wyjściem na boisko lub ulubioną aktywnością po lekcji jest w ich przypadku bardziej skuteczne niż u dziewcząt. Natomiast dziewczęta, mając lepiej wykształcony system motywacji wewnętrznej, łatwiej rozumieją sens nauki języka i czerpią 
satysfakcję z osiągania nowych umiejętności w tej dziedzinie. Metody motywowania obu płci powinny być dostosowane do tych preferencji.

Warto tu przyjrzeć się szeroko ostatnio propagowanej strategii pracy w małych grupach na lekcjach języka obcego. O ile metoda ta może przynosić dobre efekty w pracy z uczniami płci żeńskiej, zwykle nie sprawdza się w przypadku chłopców. Leonard Sax opisuje swą wizytę w szkole podstawowej w Columbii, USA, gdzie metodę tę próbowano wykorzystać na lekcjach przedmiotów ścisłych. Podczas gdy dziewczynki biorące udział w lekcji pracowały w małych grupach efektywnie, chłopcy przeciwnie. W przypadku konieczności realizacji zadań, których w pełni nie rozumieli, zamiast poprosić o pomoc nauczyciela, co mogłoby zagrozić ich wizerunkowi w grupie, wybierali raczej dygresje obok tematu zadania, rozmowy o charakterze towarzyskim czy po prostu przeszkadzanie w lekcji. Dziewczynki natomiast zdawały nauczycielowi pytania i dzięki temu sprawniej wykonywały zadane ćwiczenia. Podobnie rzecz się ma z wykorzystaniem ruchu w czasie lekcji, zwłaszcza z młodszymi grupami wiekowymi. Dziewczęta zazwyczaj wolą spokojne siedzenie w ławce i skupienie, podczas gdy większość chłopców przejawia potrzebę stosowania przerw na gimnastykę śródlekcyjną, zadania obejmujące czynności, wstawanie z miejsc, działanie.

Ważnym aspektem praktycznego wykorzystania specyfiki edukacji chłopców i dziewcząt jest wskazanie konkretnych zasad, które mogłyby ułatwić działania dydaktyczne i uczynić je bardziej efektywnymi. Oto kilka przykładów, jakie kryteria warto uwzględnić, planując ćwiczenia w edukacji zróżnicowanej:

W grupach męskich:

- Stosunkowo częsta zmiana form aktywności, np. co 5 minut (I etap edukacyjny) i 10 minut (II etap); uzasadnienie: dłuższe okresy skupienia mogą być nieosiągalne dla chłopców; potrzebują oni przejścia do skrajnie różnej formy ćwiczenia, dlatego np. po 5 minutach pracy w zeszycie przechodzimy do ćwiczeń angażujących uczniów fizycznie, w rytm piosenki.

- Przydzielanie punktów, żetonów lub plusów jako gratyfikacji za poprawną odpowiedź czy dobrą pracę; uzasadnienie: chłopcy późno wykształcają system motywacji wewnętrznej, wymierna „korzyść” z wysiłku włożonego w naukę zaowocuje lepszymi rezultatami.

- Planowanie pracy w grupach na zasadzie rywalizacji, rzadziej współpracy; powód: ta pierwsza zadziała w przypadku chłopców prawdopodobnie lepiej.

- Skorelowanie tematyki wykorzystywanych tekstów z zainteresowaniami uczniów; uzasadnienie: uczniowie płci męskiej dużo trudniej skupiają się na tekstach abstrakcyjnych lub niezwiązanych bezpośrednio z ich zainteresowaniami.

- Sprawdzenie, czy nauczyciel mówi do uczniów odpowiednio głośno; uzasadnienie: próg percepcji werbalnej chłopców wymaga dużo głośniejszego przekazu. 
W grupach żeńskich:

- Czy nauczyciel odwołuje się do motywacji wewnętrznej uczennicy, czy też „straszy” ocenami lub innymi konsekwencjami? W przypadku dziewcząt uwewnętrznienie motywacji jest warunkiem powodzenia.

- Czy plan lekcji nie zawiera zbyt wielu elementów zmiennych, np. nadmiaru różnych rodzajów ćwiczeń wymagających wstawania, przemieszczania się po sali itp.? Uczennice zazwyczaj czują się pewniej, siedząc na swoim miejscu, w warunkach sprzyjających skupieniu.

- Czy plan pracy w grupach opiera się na współpracy uczestniczek i nauczyciela? Dziewczęta pracują efektywniej, wspólnie dążąc do oczekiwanego celu, zamiast rywalizując. Chętnie przyjmują sugestie nauczycieli i starają się o dobre relacje z nimi.

- Czy nauczyciel należycie kontroluje poziom hałasu w sali? Percepcja werbalna dziewcząt nie pozwala na nadużywanie silnego głosu, zbyt głośne odtwarzanie nagrań dźwiękowych, itp.

Niektóre z opisanych wyżej różnic determinujących odmienność rozwoju oraz edukacji dziewcząt i chłopców mogą wydawać się oczywiste, zauważalne w codziennej praktyce szkolnej i wychowawczej. Moim zamiarem było przekonanie czytelnika, że owe różnice nie są postrzegane wyłącznie subiektywnie. Liczne prace specjalistyczne, które tutaj wskazywałem, dostarczają zobiektywizowanych, statystycznych danych na rzecz sensowności edukacji „rozdzielnopłciowej”. Co oczywiście nie musi być ostatecznym argumentem $\mathrm{w}$ dyskusji o modelach nauczania, nie tylko języków obcych.

\section{Bibliografia:}

Booth Alison and Nolen Patrick, 2012, 'Choosing to compete: how different are girls and boys?', Journal of Economic Behavior \& Organization, 81(2), s. 542-555.

Byrnes James, Miller David and Schafer William, 1999, 'Gender differences in risk taking: A meta-analysis', Psychological Bulletin, 125( 3), s. 367-383.

Davies Beatrice, 2004, "The gender gap in modern languages: A comparison of attitude and performance in year 7 and year 10.', Language Learning Journal, 29, str. 53-58. doi: 10.1080/09571730485200111

Duckworth Angela and Seligman Martin, 2006, 'Self-discipline gives girls the edge: Gender in self-discipline, grades, and achievement test scores', Journal of Educational Psychology, 98(1), s. 198-208.

Francis Becky, 1999, 'Lads, lasses and (new) labour: 14-16-year-old students' responses to the 'laddish behaviour and boys' underachievement' debate', British Journal of Sociology of Education, 20, s. 355-373.

Francis Becky, 2004, 'Classroom interaction and access: Whose space is it?', Gender in Education 3-19: A Fresh Approach, ed. H. Claire, 42-49. London: Association of Teachers and Lecturers.

Gardner Robert and Lambert Wallace, 1972, Attitudes and Motivation in Second 
Language Learning. Rowley: Newbury House.

Gibb Sheree, 2008, 'Effects of single-sex and coeducational schooling on the gender gap in educational achievement', Australian Journal of Education, 52(3), s. 301-317.

Gneezy Uri and Rustichini Aldo, 2004, 'Gender and com - petition at a young age', The American Economic Review, 94(2), s. 377-381.

Halpern Diane, 2007, 'The science of sex differences in science and mathematics', Psychological Science in the Public Interest, 8(1), s. 1-51.

Hughes Teresa, 2007, 'The advantages of single-sex education', National Forum of Educational Administration and Supervision Journal, 23(2), s. 5-14.

Jesse David i Moir Anne, 1989, Brainsex. The Real Difference Between Men and Women, (wyd. polskie: Płeć mózgu. O prawdziwej różnicy między mężczyzna a kobieta, 2014, Kancewicz-Hoffman N. (przeł.), Warszawa).

Kommer David, 2006, 'Boys and girls together: A case for creating gender-friendly middle school classrooms', The Clearing House: A Journal of Educational Strategies, Issues and Ideas, 79(6), s. 247-251.

Legeżyński Marcin, 2021, How to increase motivation for learning a foreign language in a single-sex school?

\section{https://drive.google.com/file/d/1jWSqSMS1GDBcvb8wTVPp0RoTkxLZF4nb/ view? usp=sharing.}

McEwen Bruce and Milner Teresa, 2017, 'Understanding the broad influence of sex hormones and sex differences in the brain', Journal of Neuroscience Research, 95(1-2), s. 24-39.

Mendez Teresa, 2004, Separating the sexes: A new direction for public education. Available at: http://www.csmonitor.com/2004/0525/p11s02-legn.html (Accessed on 21 January 2021)

Niederle Muriel and Vesterlund Lise, 2010, 'Explaining the gender gap in math test scores: the role of competition', The Journal of Economic Perspectives, 24(2), s. 129-144.

The Nuffield Foundation (2000) Languages: The next generation. London: Nuffield Ormerod, M.B. (1975) 'Subject preference and choice in co-educational and single-sex secondary schools', British Journal of Eductional Psychology, 45(3), s. 257-267.

Riordan Cornelius, 2015, Single-sex schools: a place to learn. Lanham: Rowman\&Littlefield.

Sax Leonard, 2005, Why Gender Matters: What Parents and Teachers Need to Know about the Emerging Science of Sex Differences, New York: Random House.

Spielhofer Thomas, Benton Tom and Schagen Sandie, 2004, 'A study of the effects of school size and single-sex education in English schools', Research Papers in Education, 19(2), s. 133-159.

Van der Slik Frans, Van Hout Roeland and Schepens Job, 2014, 'The Gender Gap in Second Language Acquisition: Gender Differences in the Acquisition of Dutch among Immigrants from 88 Countries with 49 Mother Tongues', Jour- 
Razem czy osobno? Znaczenie płci w szkolnej nauce języka obcego

nal of Economic Behavior \& Organization, 99, s. 126-154.

\section{O Autorze:}

Marcin Legeżyński - absolwent Wyższej Szkoły Języków Obcych w Poznaniu oraz Oxford Brookes University. Przez kilka lat pracował w różnego typu szkołach publicznych Wielkiej Brytanii, obecnie nauczyciel języka angielskiego w niepublicznej Szkole Podstawowej „Skrzydła” Fundacji Sternik-Poznań.

Polonistyka. Innowacje 
